\title{
DEMAND FORECAST IN THE EMERGENCY DEPARTMENT IN MINAS GERAIS, BRAZIL
}

\author{
PREVISÃO DE DEMANDA NO DEPARTAMENTO DE EMERGÊNCIA EM \\ MINAS GERAIS, BRASIL
}

\author{
Franciele Guimarães de BRITO' ${ }^{1}$; Elmiro Santos RESENDE' \\ Aurélia Aparecida de Araújo RODRIGUES ${ }^{3}$; Marcelle Aparecida Barros JUNQUEIRA ${ }^{4}$; \\ Vívian Ribeiro BARRETO ${ }^{5}$; João Batista DESTRO FILHO ${ }^{6}$ \\ 1. Pos graduated by Federal University of Uberlândia, $\mathrm{PhD}$ in biomedical engineering from the Federal University of Uberlândia; 2. \\ Professor at the Federal University of Uberlândia in the Medicine School, PhD from the São Paulo Federal University; 3. Professor at \\ the Federal University of Uberlândia in the Mathematics School, PhD from the Pontifical Catholic University of Rio de Janeiro; 4. \\ Professor at the Federal University of Uberlândia in the Nursing School, PhD from the São Paulo Federal University of Ribeirão Preto; \\ 5. Graduated in Statistic of the Federal University of Uberlândia; 6. Professor at the Federal University of Uberlândia in the Electrical \\ Engineering School, PhD from the Nice-Sophia Antipolis University of France
}

\begin{abstract}
This study presents a mathematical model to carry out the demand forecasts in relation to patientes classified as green in the emergency department of a municipality in Minas Gerais, Brazil. In addition, another approach will investigate whether the green patients demand remains the same over the weekend, as compared to the weekdays, since there is no support from Primary Health Care units over the weekend. A retrospective study of the emergency service in the municipality of Monte Carmelo was carried out from January 2014 to December 2017.The time series of the patients classified as green during the host by the nurse, according to the Manchester Triage Scale, was analyzed in the temporal domain for the construction of a parametric model with the purpose of realizing the demand forecast. The Manchester Triage Scale has been adopted in most emergency department as a guiding instrument for risk classification, prioritizing the most serious cases. The data processing was fulfilled using Software R Version 3.4. The ARIMA model $(1,1,1)$ presented a better fit for this forecast. The predictions of this model are values close to those observed for the number of patients seen that ranges from 1780.4 to 1796.6 patients per month. In relation to the demand of patients classified as green at the weekend, it has shown that it is slightly lower than the weekend, but it is still an expressive demand. The application of the models must be seen by the managers as a tool to aid decisions, thus it must support processes of planning, management and evaluation of public policies. In this context, mathematical models for demand forecasting are an instrument for management care and services.
\end{abstract}

KEYWORDS: Triage. Health service needs and demands. Public health.

\section{INTRODUCTION}

A Integrated Delivery Systems in the scope of Unified Health System was established as a strategy to overcome the fragmentation of attention and management in the Health Regions and improve the political and institutional functioning of the Unified Health System, with a view to assuring users the set of actions and services that they need with effectiveness and efficiency (BRASIL, 2010).

The emergency department is an important component of this health care and requires the organization of local health systems and the articulation between the different levels of attention to provide a qualified and decisive service to the emergency department. Health care in these situations should be articulated with Primary Health Care, since in addition to its effective functioning, it is necessary to develop health promotion actions and prevent diseases and injuries, diagnosis, treatment, rehabilitation and palliative care.

Health actions and services must be organized so that they function in a harmonious and integrated way, overcoming the hegemonic logic of fragmentation of the health service organization within isolated programs, which are isolated and without connection with the epidemiological needs of the population and socio-demographic conditions of the region (BRASIL, 2013).

In an attempt to address the challenges related to the organization of emergency services, the actions of the Ministry of Health have been focused on the need to reorganize the work process in order to meet the different levels of specificity and resolution in the care giving to patients with acute aggravations (BRASIL, 2009).

In this context of reorganization of the processes, the Ministry of Health through the 
National Policy of Humanization of Attention and Management of the Unified Health System proposes innovations in managerial practices and health production practices. Thus, in 2004, the User Embracement with Risk Classification was pointed out as a device for change in health care, management and production in health.

The User Embracement with Risk Classification in the emergency department instituted in 2011, forms the basis of the process and of care flows, a requirement of all points of attention (BRASIL, 2011). Understood as a relational technological intervention device, the User Embracement with Risk Classification is guided by qualified listening, link building, guarantee of access with accountability, resolution of health services, as well as prioritization of the most serious patients for care (BRASIL, 2009).

Therefore the User Embracement with Risk Classification is a guiding guide for attention and management of the emergency department, a measure of intervention for reorganization of urgency and emergency entry and in the implementation of networked health production. The Ministry of Health recommends that risk classification should follow a guiding protocol (BRASIL, 2009).

At the global level, the most used protocols are: Australian Triage Scale, Canadian Emergency Department Triage and Acuity Scale, Emergency Severity Index e Manchester Triage Scale (PINTO JUNIOR et al., 2012).

In this way, classification systems were created with the purpose of prioritizing service in an objective manner and based on the degree of risk. In Brazil, among the existing screening scales, the Manchester Triage Scale (MTS) has been adopted in most emergency department as a guiding instrument for risk classification, prioritizing the most serious cases.

In this scale, the most frequent complaints of the patients treated in the emergency department are arranged in flow charts. Each flowchart has a set of discriminators that represent the signs and symptoms related to the main complaint presented by the patient. Each level of clinical priority has discriminators that define the patient's level of risk. Once classified, it is important that the patient is monitored and reevaluated, since his clinical condition may worsen or decrease (MACKWAYJONES et al., 2010).

The assignment of risk to patients consists of a complex decision-making process in which nurses have been the most appropriate professionals to perform this task (FORSGEREN et al., 2012).
The MTS includes levels of priority, color to be assigned, and an estimate of waiting time for medical care. Based on the identification of the user's main complaint by the nurse, a specific flowchart is selected, guided by the discriminators.

Thus, the MTS screening scale classifies the patient into five priority levels: level 1 red (emergent, must receive immediate medical attention); level 2 orange (very urgent, medical evaluation in up to 10 minutes); level 3 yellow (urgent, medical evaluation in up to 60 minutes); level 4 green (not very urgent, medical evaluation in up to 120 minutes); level 5 blue (not urgent and can wait up to 240 minutes for medical attention) (MACKWAY-JONES et al., 2010).

The reality of the emergency department around the world is overcrowded. The points of attention to acute conditions began to have management difficulties due to the increase of chronic conditions and consequently the increase of the use of these services, becoming the main cause of people's dissatisfaction with their health systems. The fact is that at the moment when the correlation between the presence of chronic conditions poorly managed by the health system and the emergency department, it is obvious that the vast majority of patients who enter today through the urgency presents acute exacerbations of chronic conditions (CORDEIRO JÚNIOR, 2008).

These services serve a considerable volume of users that could be served in less complex units (FRANGO et al., 2018). However, Primary Health Care is organized to perform scheduled care, causing surplus demand to be informally referred informally to the emergency department (GHEN et al., 2015).

The Primary Health Care is the first level of care and coordinates care at all points of care, presents a great capacity for resolving primary care about the health needs of the population. The Primary Health Care as a care coordinator must also be understood as the communication center of the Integrated Delivery Systems, which means being able to order the flows and against the flows of people, the products and the information between the different components of the networks.

The implementation of the Family Health Strategy aimed at reorganizing the Primary Health Care in Brazil, according to Unified Health System guidelines. The Family Health Strategy should focus on the intervention of factors that put health at risk, in order to promote the quality of life of the Brazilian population. Thus, the health care model, recommended by the Unified Health System, has an 
emphasis on Family Health Strategy and the principles of Primary Health Care.

However, the Family Health Strategy is a paradigmatic historical, procedural and tense change in political conflicts in the conformation of the health system. Thus, it still perpetuates the traditional model of care, with health cut short by public health programs, instability of promotion and surveillance actions, focus on spontaneous demand, in the illness and in the medical professional (FRANGO et al., 2018). It should be noted that patients classified as green and blue by MTS do not fit as urgent cases, therefore, they could be treated in health services of less complexity as in the Primary Health Care units through the Family Health Strategy.

In this way, it is necessary to organize the Integrated Delivery Systems on a permanent basis, especially the emergency department. Proper planning is necessary for this to occur. The time series can be useful in managing this demand by analyzing the actual number of services performed over time.

A time series is any set of observations ordered in time (MORRETIN; TOLOI, 2006). The observation of the behavior of needs in a given population and acquisition of knowledge about the likely evolution of the series over the next few years is an important tool in planning.

The basic principle underlying ARIMA models considers data correlations studied at different times. Data analysis using the time series technique, in particular the ARIMA model, is essential for planning and management decisions, based on the predictions. This model is adopted in different research fields, such as epidemiology (Lin, 2015), economics (Rotela Junior, 2014), earth sciences (Shirvani, 2015). When applications to health care are considered, one should point out recent works as follows. Zhirui He and Hongbing Tao published a study using the ARIMA method to describe the epidemiology of influenza virus in children in Wuhan, China, during the nine influenza seasons (2007-2015), in order to to predict the different types of influenza in the future $(\mathrm{He}$ and Tao, 2018).

However, the analysis of care data in the emergency department is of fundamental importance to monitor; plan and intervene. Thus, this study has as main objective is to present a suitable model to carry out the predictions regarding the services classified as green in the emergency department of the municipality of Monte Carmelo, since these represent the greatest demand in the service. In addition, another approach will investigate whether the green patients' demand remains the same over the weekend, as compared to the weekdays, since there is no support from Primary Health Care units over the weekend. This study aimed to present a mathematical model to carry out the demand forecasts in relation to patientes classified as green in the emergency department of a municipality in Minas Gerais, Brazil.

\section{MATERIAL AND METHODS}

A retrospective study of the emergency department of the municipality of Monte Carmelo was carried out in January/2014 to December/2017. All the patients classified as green in the emergency unit of the municipality of Monte Carmelo during the study period were included. The research was carried out after approval by the Research Ethics Committee of the Federal University of Uberlândia Minas Gerais, opinion number 1.990.248 and 2.360 .801 .

The data collected during the period considered were organized into tables of Excel composing a database. This database contains the time series and their filters that correspond to the priority levels adopted by the MTS. The filter in a database is the designation used for any criteria used in the data grouping (PELLEGRINI, 2000).

One of the approaches used in the analysis of time series is made in the time domain and the proposed mathematical models are parametric models. The goal is to build models for the series with certain purposes.

For the application of the models were used all the observations of the patients attended per month in the urgency and emergency service in the period mentioned that received the green classification during the reception by the Nurse of the unit.

The software used for data processing was Software R Version 3.4 (R DEVELOPMENT CORE TEAM, 2018). The free software $R$ is a language and environment for statistical computing and graphical techniques, in which among the statistical varieties includes analysis of time series. Through this data processing, a forecast horizon of twelve months was made for the time series.

The forecasting methods are classified according to their approaches, which are: quantitative; qualitative or the combination of the two. For prediction using quantitative methods, it is necessary to construct mathematical models based on historical data that describe the variation of 
demand over time, the time series models (PELLEGRINI, 2000).

The methodology for time series proposed by Box and Jenkins in 1976 is developed based on three steps: identification of the model to be used; estimation of the identified parameters and verification of the model obtained (BOX; JENKINS, 2015). It should be emphasized the importance of verifying the stationarity and seasonality condition of the series before beginning the described steps (WANG, 2011). The steps described are repeated several times by testing several models, until obtaining a satisfactory model. After verification of these conditions, the model can be used for forecasting (FAVA, 2000).

For more than half a century Autoregressive Integrated Moving Average (ARIMA) models have been used in several areas that forecast through time series (HO et al., 2002). There are general and specific applications performed in the medical field (WERNER; RIBEIRO, 2003).

A methodology widely used in the analysis of parametric models is known as the Box and Jenkins approach. This methodology consists in adjusting the integrated autoregressive models of moving averages, ARIMA (p, d, q), to a set of data, where AR (p) is the autoregressive process of order $\mathrm{p}$; (d) is the number of differences applied; MA (q) the process of moving averages of order $q$ (MORRETIN; TOLOI, 2006).

Thus, the general structure ARIMA (p, d, q) is expressed by equation 1 (MORRETIN; TOLOI, 2006).

$$
\Phi(\mathbb{B}) \nabla^{d} z_{t}=\ominus(\mathbb{B}) a_{t}
$$

The identification of the appropriate model is done through the functions of autocorrelation and partial autocorrelation by observing the lags of the graphs. The Autocorrelation Function (ACF) is expressed by equation 2 (MORRETIN; TOLOI, 2006).

$$
\rho_{k}=\frac{\operatorname{cov}\left[z_{k}, Z_{k-k}\right]}{\operatorname{Var}\left[Z_{\mathrm{k}} 3\right.}, k=0, \pm 1 \pm 2, \ldots
$$

The Partial Autocorrelation Function (PACF) corresponds to the correlation between two serial observations, $Z_{t}$ and $Z_{t-k}$, removing the effect of the observations $\mathrm{Zt}-1, \mathrm{Zt}-2, \ldots, \mathrm{Zt}-(\mathrm{k}+1)$, and it is denoted by equation 3 (MORRETIN; TOLOI, 2006).

$$
\emptyset_{k h}=\operatorname{Corr}\left(Z_{t}, Z_{\mathrm{t}-k} / Z_{\mathrm{t}-1, \ldots,} Z_{\mathrm{t}-(k+1)}\right), k=0, \pm 1, \pm 2 \ldots(3)
$$

In summary, it is assumed that the strategy for the construction of the model will be based on an interactive cycle, in which the structure of the model is based on the data itself. The stages of the cycle are: a general class of models is considered for analysis; there is identification of a model, based on autocorrelation, partial autocorrelation and other criteria; then it comes to the estimation phase, in which the parameters of the identified model are estimated and finally, there is the verification or diagnosis of the adjusted model, through the residue analysis, to know if it is suitable for the purposes in view (forecast, for example) (MORRETIN; TOLOI, 2006).

It should be emphasized that the most important phase of the ARIMA model is the identification of the $p, d, q$ values of the ARIMA model ( $\mathrm{p}, \mathrm{d}, \mathrm{q})$, as well as preliminary estimates of the parameters to be used in the estimation stage (MORRETIN; TOLOI, 2006) .

Statistical tests should also be used throughout all stages of the cycle so that the choice of model parameters is the most appropriate. Among these tests we can mention the Signal Test (CoxStuart) to analyze trend; Friedman's test to verify seasonality; Dickey-Fuller test for steady behavior; Ljung-Box test and Shapiro-Wilk test for residue analysis and diagnosis (MORRETIN; TOLOI, 2006).

\section{RESULTS AND DISCUSSION}

The municipality of Monte Carmelo, located in the mesoregion of the Triângulo Mineiro and Alto Paranaíba, in the State of Minas Gerais. Compared to the previous year, a total population of the municipality corresponded to 45772 population, with a demographic base of 34.08 population $/ \mathrm{km}^{2}$ (IBGE, 2018).

The emergency department of the municipality reached 120230 patients in the period from January 2014 to December 2017, with an average of 2470 patients per month. As shown in Graph 1, all patients who arrive at the service are hosted by the Nurse Practitioner and are classified by MTS. It should be noted that 3394 patients, in this period, were classified as whites, because they sought unity without any clinical complaint.

The statistical analysis in Table 1 shows that patients classified as green correspond to the higher demand for care in the service $(60.93 \%)$, an average of 1526.10 visits per month.

This finding is similar to the study carried out on the clinical demand in the Emergency department in central western of Minas Gerais, 
health care center, which found that $61 \%$ of the patients seen were classified as green. The main complaints related to these patients were
"Indisposition in the adult" (40.1\%), "limb problem" (14.4\%), "headache" (10.8\%) and "abdominal pain" (5.9\%) (DINIZ et al., 2014).

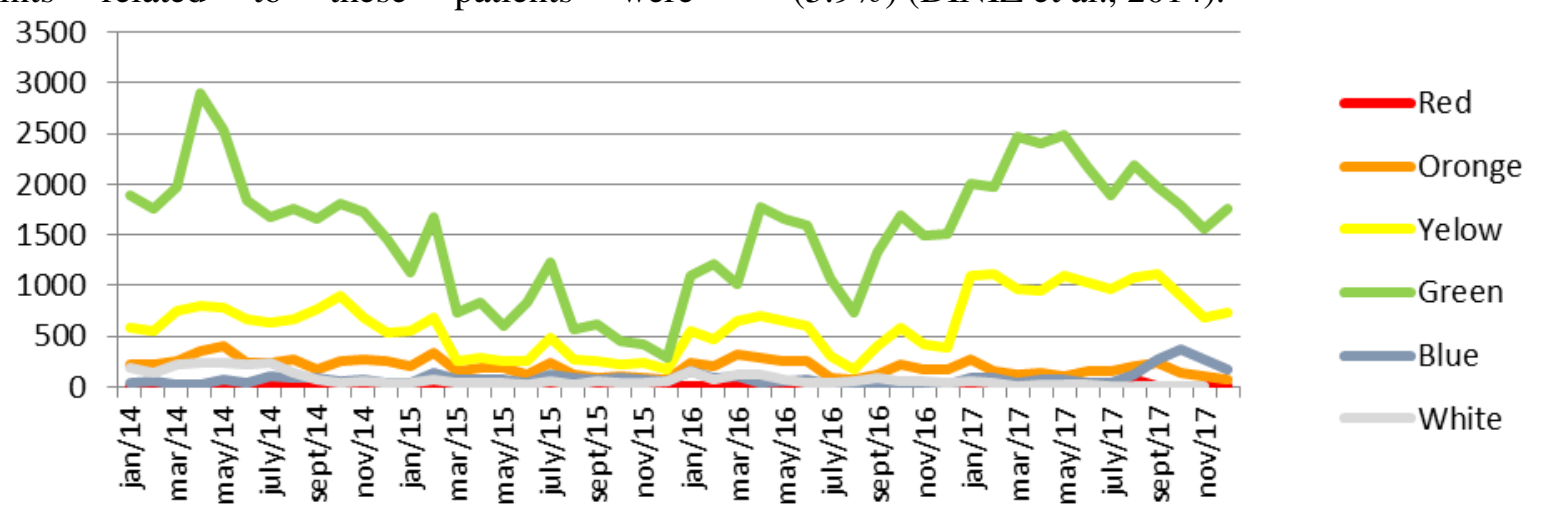

Graph 1: Time series of the number of patients classified by the Manchester Triage Scale per month.

Table 1. Statistical analysis for patients classified by the Manchester Triage Scale, 2014 to 2017

\begin{tabular}{lccccccc}
\hline & $\mathbf{N}$ & $\overline{\boldsymbol{X}}$ & $\mathbf{M d}$ & $\mathbf{Q 1}$ & $\mathbf{Q 3}$ & $\mathbf{s}$ & $\mathbf{C V}$ \\
\hline Red & 480 & 10 & 7 & 3.75 & 12 & 11.71 & $117.07 \%$ \\
Orange & 9339 & 194.56 & 194.5 & 126.25 & 248 & 79.43 & $40.82 \%$ \\
Yellow & 29803 & 620.89 & 640 & 396 & 790.5 & 281.65 & $45.36 \%$ \\
Green & 73253 & 1526.10 & 1669.5 & 1087.25 & 1883.25 & 616.66 & $40.41 \%$ \\
Blue & 3961 & 82.52 & 68.5 & 39.75 & 92.75 & 69.83 & $84.62 \%$ \\
\hline
\end{tabular}

In the present study we analyzed the time series of patients classified as green attended per month in the mentioned period due to the high demand of this type of patients. By studying this series will be possible to obtain a suitable model to carry out the forecasts in the next 12 months.

The first step in the analysis of a time series is the construction of its graph, which will reveal important characteristics such as trend, seasonality, variability, outliers, etc. The original time series of the number of patients attended per month have 48 observations for each priority level, from the period between 2014 and 2017, graph 1. It is not possible to perceive the presence of trend and seasonality in the series in the groups of green patients (not very urgent) that will be analyzed in the study.

In addition to the graphical inspection, it is possible to use statistical hypothesis tests to verify if there are trends and seasonality in the series. Since most procedures of statistical analysis of time series assume that they are stationary, it is necessary to transform the original data if they do not form a stationary series. The most common transformation is to make successive differences from the original series until a stationary series is obtained. In normal situations, it will suffice to take one or two differences so that the series becomes stationary (MORRETIN; TOLOI, 2006).
Thus, to verify if the data present a biased behavior, the Signal Test (Cox-Stuart) was carried up and to verify the seasonality the Friedman Test was carried up too. At the 5\% level of significance, there is statistical evidence that can guarantee that the series have no trend $(\mathrm{p}$-value $=0.8388)$, or seasonality ( $p$-value $=0.06041)$.

An analysis of the variation in the number of visits was also carried up and it was found that it has high variability (coefficient of variation = 380270.3). Thus, the first difference in the data was applied and the Dickey-Fuller Test was carried up to certify that this transformation was enough to make the series stationary. Thus, at the 5\% level of significance, there is statistical evidence that can guarantee that the series has stationary behavior ( $p$ value $=0.01$ )

The next step of this analysis is to identify the filters that will compose the model, that is, the presence and number of self-correcting components and moving averages, respectively. For this, the technique commonly used is the analysis of the ACF and PACF. The decision is made based on the standards identified for each of the functions, ACF and PACF (JACOBS et al., 2003).

Thus, we performed an analysis of the correlograms of the Autocorrelation ACF and PACF of the original series to investigate the significant 
lags. Among the several models tested, the ARIMA model $(1,1,1)$ presents a better prediction.

To obtain a model that fit the data was used the model ARIMA. The ARIMA models were described by Box and Jenkins in 1976 and are characterized as one of the most widespread methodologies for time series analysis (MADDALA, 2003; MORRETIN; TOLOI, 2006; BOX; JENKINS, 2015).

The analysis of the prediction errors allows to choose, among the applied models, the one that is most adequate to make predictions for the series under study (AFONSO et al., 2011). Thus, to fit the most adequate model to perform predictions of the number of green patients attended per month, tests were done with the two different models, comparing them based on the Mean Absolute Error (MAPE) (NOVAES et al., 2010; ROSALES-LÓPEZ et al., 2018). For the green patients, the ARIMA model $(1,1,1)$ obtained a prediction error of $13.98 \%$, since it was the lowest value, it uses it to make the predictions of the 12 months.

For the selected ARIMA model, it was investigated whether or not it adequately represents the data (MORRETIN; TOLOI, 2006). In this case, the model residues can not be autocorrelated. If this condition is not verified, it is necessary to search for another model (MORRETIN; TOLOI, 2006; FAVA, 2000). For the residue independence test, the LjungBox test was statistically confirmed to be independent ( $\mathrm{p}$-value $=0.9262$ ). To analyze the normality of the residues the Shapiro-Wilk Test was carried up, proving that the residues have a normal distribution ( $p$-value $=0.5713$ ). When analyzing the homogeneity of the variances, it was verified that the residues have random behavior, variance is constant.

According to the validated model, ARIMA $(1,1,1)$, the numbers of care provided in the next 12 months for the green patients are represented by the blue line in the graph (Figure 1). In January 2018, the number of patients expected is 1780.4, in February 2018, the number of patients expected is 1789, and so on. According to the forecast presented for the year 2018 in figure 1, the number of patients varies between 1780.4 and 1796.6 patients per month.

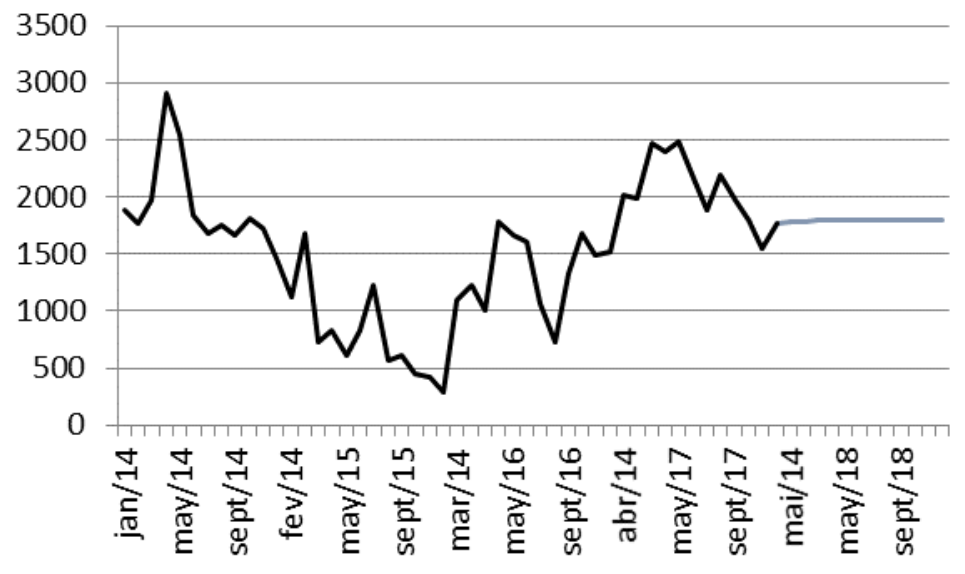

\begin{tabular}{rc}
\hline & Prediction \\
\hline Jan/18 & 1780.4 \\
Feb/18 & 1789 \\
Mar/18 & 1793.1 \\
Apr/18 & 1795 \\
May/18 & 1795.9 \\
Jun/18 & 1796.4 \\
Jul/18 & 1796.6 \\
Aug/18 & 1796.6 \\
Sep/18 & 1796.7 \\
Oct/18 & 1796.7 \\
Nov/18 & 1796.7 \\
Dec/18 & 1796.7 \\
\hline
\end{tabular}

Figure 1. Time series with predicted number of patients for the next 12 months

The ARIMA model was used to predict monthly visits to an emergency department in the southern region of Taiwan, using the time series from 2009 to 2016. In this study the ARIMA model $(0,0,1)$ was considered appropriate to provide for future emergency consultations at that hospital. The authors point out that the results can be used to assist in decision-making processes and the findings provide new insights into the reasons for overcrowding in the emergency department (JUANG et al., 2017).
Another study conducted at Illinois Medical Hospital, Chicago, which has 897 tertiary care beds, evaluated the predictability of patient volume using a variety of known prediction techniques (exponential smoothing methods, ARIMA, seasonal ARIMA, and conditional autoregressive generalization). Among these techniques ARIMA presented the lowest MAPE, that is, the best performance in predicting the volume of patients in the hospital. Thus, the technique can accurately predict the volume of patients in the near future (KIN et al., 2014). 
In Canada, it was also analyzed the time series of patients who were admitted to the emergency room in the Province of Ontario with Chronic Obstructive Pulmonary Disease. The ARIMA method was used to predict future rates of hospital and emergency room visits. The authors emphasize the relevance of the information generated in order to alert doctors, hospitals and decision makers about the increasing need for resources and policies to meet the future needs of the population (GERSHON et al., 2017).

The importance of generating quality information for the planning, monitoring and evaluation of health services provided to the population in scope of the Unified Health System should be emphasized in order to have a more effective and efficient model, appropriate to the characteristics of the population of each region of Brazil (TOMASI et al., 2011). Thus, the time series can be useful in the management of demand in the urgency and emergency services by analyzing the actual number of services carried out. In this way it allows the observation of the behavior of the needs in a certain population and acquisition of knowledge about the probable evolution of the series over the next years.

The demand forecast from the time series analysis is a tool that should be used to improve the analysis of processes and decision making in health services, thus contributing to the more efficient use of the public budget related to health. Studies indicate that public health expenditures in Brazil in relation to PIB consume about $2.8 \%$ of all wealth generated in the country. The correct and efficient administration of these resources by public entities becomes a preponderant factor for improving the health of society and managing disbursements (SIMÕES; SILVA, 2017).

In another approach, the reflex of the Primary Health Care units closed at weekends was evaluated to verify a possible overhead in the emergency department. Thus, patients classified as green were divided into two groups, those who were seen during the week and those who were seen at the weekend. Following, the daily average of care for these two groups was obtained. The Graph 2 shows the evolution of the daily average care of the two groups in the period studied.

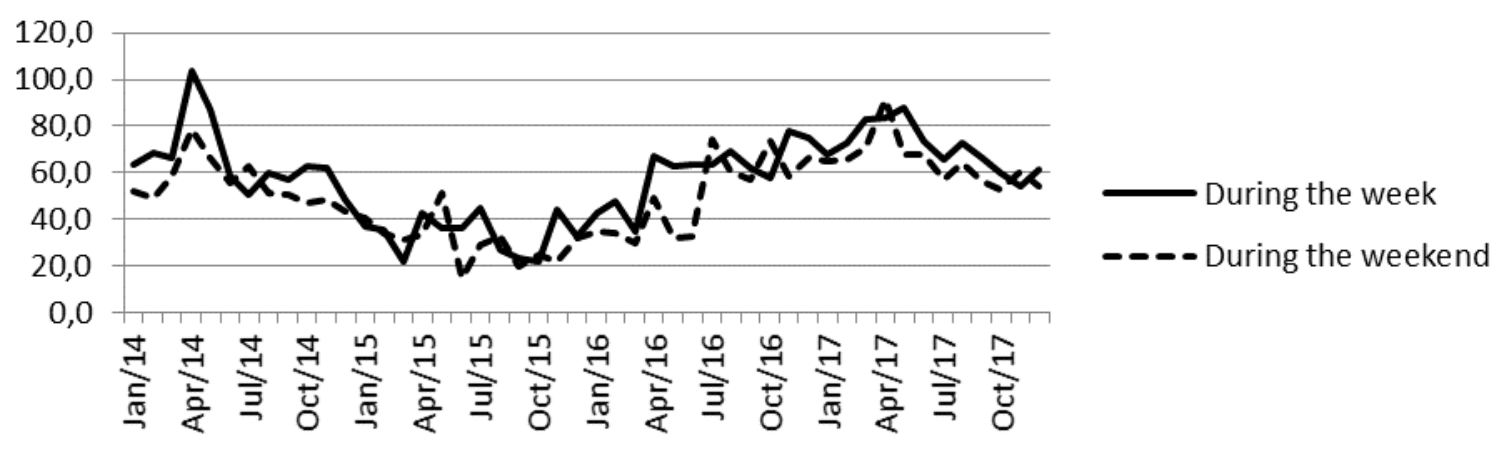

Graph 2. Time series for the daily average of patients during the week and the weekend

In this graph 2, similar behavior is observed for the two groups, with the average number of visits at the weekend being slightly lower than the average number of visits during the week. This statement was confirmed by the unilateral $\mathrm{Z}$ test ( $\mathrm{p}$ value $=0.0251)$. Thus, it can be seen that even APS units providing support for urgency and emergency services during the weekdays, there is still a significant demand for green patients at weekends, which is slightly lower than during the week.

The population believes that the urgency and emergency service provides fast, safe and effective care, for being able to attend the most serious cases. This, together with dissatisfaction with the Primary Health Care services, leads to overcrowding of urgency and emergency services (CHEN et al., 2015).

An analysis of Primary Health Care practiced in Unified Health System shows a privilege of uniprofessional attention, strongly focused on the doctor, and carried out through 15 minute consultations (MENDES, 2011). There is even a very widespread programming parameter of four medical consultations per hour (SESMG, 2007).

In national or international experiences, it is a common reality that the urgency and emergency service is the main doorway of the user to the health system (FRANGO et al., 2018). A study carried out in southern Brazil showed that $58.2 \%$ of the patients reported have been looking for the first aid because 
they believed that this service would be better able to serve them than the Primary Health Care units (CARRET et al., 2007).

The time series used in this study was limited four years ago because during the survey there was no further information available. Although there is no allowance in the literature for a minimum number of data, further studies should be performed with a larger set of observations ordered over time.

\section{CONCLUSIONS}

Using the time series for the number of patients classified by the Manchester Screening Protocol as green, the results of the present study suggest that the ARIMA model $(1,1,1)$ presents a better fit for this prediction. The predictions of this model are values close to those observed, for the number of patients attended that ranges between 1780.4 and 1796.6 patients per month.

It emphasizes the importance of the use of mathematical models of forecasting in Integrated Delivery Systems. The application of these models should be seen by the managers as a tool to aid decisions, so it should subsidize processes of management, planning and evaluation of public policies.

On the other hand, the demand of patients classified as green at the weekend is slightly lower than that of the weekend, but it is still an expressive demand. This demand for patients who do not fit as an urgent case during the weekdays shows that PHC does not always act as a gateway to the health care system in cases of less complexity. However, Primary Health Care should be the fundamental level of Unified Health System, being the first contact of the population with this system.

Thus, it is necessary to rethink the practice of Integrated Delivery Systems in the scope of the Unified Health System. The emergency department should work in a coordinated manner with the Primary Health Care and all other health care points of the Integrated Delivery Systems so that the patient has the necessary care, according to his need, at the point of appropriate attention of care. The mathematical models for demand forecasting can improve care management tools and services, thus making an extraordinary contribution to the scientific and technological development.

RESUMO: Este estudo apresenta um modelo matemático para realizar as previsões de demanda em relação aos pacientes classificados como verdes no departamento de emergência de um município de Minas Gerais. Além disso, outra abordagem investigará se a demanda dos pacientes verdes permanece a mesma no final de semana, em relação aos dias da semana, uma vez que não há apoio das unidades de Atenção Primária de Saúde no final de semana. Um estudo retrospectivo do serviço de emergência no município de Monte Carmelo foi realizado no período de janeiro de 2014 a dezembro de 2017. A série temporal dos pacientes classificados como verdes durante o acolhimento pelo enfermeiro, segundo o Sistema de Triagem de Manchester, foi analisada no domínio temporal para a construção de um modelo paramétrico com a finalidade de realizar a previsão de demanda. O Sistema de Triagem de Manchester foi adotado na maioria dos serviços de emergência como instrumento orientador para a classificação de risco, priorizando os casos mais graves. O processamento de dados foi realizado usando o Software R Versão 3.4. O modelo ARIMA $(1,1,1)$ apresentou melhor ajuste para essa previsão. As previsões deste modelo são valores próximos aos observados para o número de pacientes atendidos que variam de 1780.4 a 1796.6 pacientes por mês. Em relação à demanda de pacientes classificados como verdes no final de semana, constatou que é ligeiramente inferior a do fim de semana, mas ainda é uma demanda expressiva. A aplicação dos modelos deve ser vista pelos gestores como uma ferramenta para auxiliar as decisões, portanto, deve apoiar processos de planejamento, gestão e avaliação de políticas públicas. Nesse contexto, os modelos matemáticos para previsão de demanda são um instrumento de atendimento e serviços gerenciais.

PALAVRAS CHAVE: Triagem. Necessidades e demandas de serviços de saúde. Saúde pública.

\section{REFERENCES}

AFONSO, M.W.; MOREIRA FILHO, R.M.; NOVAES, M.L.O. Aplicação de modelos de previsão de demanda em uma farmácia hospitalar. Relatórios de pesquisa em Engenharia de Produção, v. 11, n. 4, 2011. 
BOX, G.E.P; JENKINS, G.M.; REINSEL, G.C.; LJUNG, G.M. Time Series Analysis: Forecasting and Control. 5th ed. San Francisco: John Wiley \& Sons; 2015, 712p.

BRASIL, portaria $n^{\circ} 4.279$, de 30 de dezembro de 2010. Estabelece diretrizes para a organização da Rede de Atenção à Saúde no âmbito do Sistema Único de Saúde (SUS). Biblioteca Virtual em Saúde. Avaible on: www.bvsms.saude.gov.br. Acessed on: 28 sep 2018.

BRASIL. Ministério da Saúde. Portaria n. 1600, de 7 de julho de 2011. Reformula a Política Nacional de Atenção às Urgências e institui a Rede de Atenção às Urgências no Sistema Único de Saúde (SUS). Brasília; 2011. Avaible on: http://bvsms.saude.gov.br/bvs/saudelegis/gm/2011/prt1600_07_07_2011.html. Acessed on: 30 sep 2018.

BRASIL. Ministério da Saúde. Secretaria de Atenção à Saúde. Departamento de Atenção Especializada. Manual instrutivo da Rede de Atenção às Urgências e Emergências no Sistema Único de Saúde (SUS) / Ministério da Saúde, Secretaria de Atenção à Saúde, Departamento de Atenção Especializada. Brasília: Editora do Ministério da Saúde, 2013.

BRASIL. Ministério da Saúde; Secretaria de Atenção à Saúde. Política Nacional de Humanização da Atenção e Gestão do SUS. Acolhimento e classificação de risco nos serviços de urgência. Brasília: MS; 2009.

CARRET, M.L.V; FASSA, A.G.; KAWACHI, I. Demand for emergency health service: factors associated with inappropriate use. BMC Health Serv Res, v. 7, 2007. DOI: https://dx.doi.org/10.1186/1472-6963-7-131

CHEN, W.; WATERS, T.M.; CHANG, C.F. Insurance impact on non urgent and primary caresensitive emergency department use. Am J Manag Care, v. 21, n. 3, p 210-7, 2015.

CORDEIRO JÚNIOR, W. A gestão de risco na urgência. Belo Horizonte: Grupo Brasileiro de Classificação de Risco; 2008.

DINIZ, A.S.; SILVA, A.P.; SOUZA, C.C.; CHIANCA, T.C.M. Demanda clínica de uma unidade de pronto atendimento, segundo o protocolo de Manchester. Rev. Eletr. Enf., v. 16, n. 2, p. 312-2, abr/jun 2014. DOI: http://dx.doi.org/10.5216/ree.v16i2.21700.

FAVA, V.L. Análise de Séries de Tempo. In: Vasconcellos MAS, Alves D. Manual de econometria: nível intermediário. São Paulo: Atlas; 2000.

FORSGREN, B.; FORSMAN, S.; CARLSTROM, E.D. Nurses working with Manchester triage. The impact of experience on patient security. Australas. Emerg. Nurs. J., v. 15, p. 100-7, 2012. DOI:

https://dx.doi.org/10.1016/j.aenj.2012.02.001

FRANGO, B.C.T.M.; BATISTA, R.E.A.; CAMPANHARO, C.R,V,; OKUNO, M.F,P; LOPES, M.C.B.T. Associação do perfil de usuários frequentes com as características de utilização de um serviço de emergência. Rev. Min. Enferm., v. 22, p. e-1071,2018. DOI: http://dx.doi.org/10.5935/1415-2762.20180001

GERSHON, A.; THIRUCHELVAM, D.; MOINEDDIN, R.; ZHAO, X.Y.; HWEE, J.; To, T. Forecasting Hospitalization and Emergency Department Visit Rates for Chronic Obstructive Pulmonary Disease: A TimeSeries Analysis. Ann Am Thorac Soc., v. 14, n. 6, p. 867-873, 2017. DOI:

https://dx.doi.org/10.1513/AnnalsATS.201609-717OC.

HE, Z.; TAO, H. Epidemiology and ARIMA model of positive-rate of influenza viruses among children in Wuhan, China: A nine-year retrospective study. Int J Infect Dis. 2018; sep; 74:61-70. DOI: https://dx.doi.org/10.1016/j.ijid.2018.07.003.

HO, S.L.; XIE, M.; GOH, T.N. A comparative study of neural network and Box-Jenkins ARIMA modeling in time series prediction. Computers \& Industrial Engineering, v. 42, p. 371-75, 2002. 
IBGE, Instituto Brasileiro de Geografia e Estatística. Panorama Monte Carmelo [Internet]. Brasília: Ministério do Planejamento, Desenvolvimento e Gestão. Avaible on: https://cidades.ibge.gov.br/brasil/mg/monte-carmelo/panorama. Acessed on: 01 sep 2018.

JACOBS, W.; ZANINI, R.R.; COSTA, M. Estudo comparativo de séries temporais para previsão de vendas de um produto. Iberoamerican Journal of Industrial Engineering, v. 6, n. 12, p 112-33, 2014.

JUANG, W.C.; HUANG, S.J.; HUANG, F.D.; CHENG, P.W.; WANN, S.R. Application of time series analysis in modelling and forecasting emergency department visits in a medical centre in Southern Taiwan. BMJ Open, v. 7, n. 11, p. e018628, dec. 2017. DOI: https://dx.doi.org/10.1136/bmjopen-2017-018628.

KIN, K.; LEE, C.; O'LEARY, K.J.; ROSENAUER, S.; MEHROTRA, S. Predicting Patient Volumes in Hospital Medicine: A Comparative Study of Different Time Series Forecasting Methods. Tech rep. Northwestern University. January 23, 2014.

LIN, Y.; CHEN, M.; CHEN, G.; WU, X.; LIN, T. Application of an autoregressive integrated moving average model for predicting injury mortality in Xiamen, China. British Medical Journal Open. 2015; 5:e008491. DOI: https://dx.doi.org/10.1136/bmjopen-2015-008491

MACKWAY-JONES, K.; MARSDEN, J.; WINDLE, J. Sistema Manchester de Classificação de Risco. $2^{\mathrm{a}}$ ed. Brasil: Grupo Brasileiro de Classificação de Risco; 2010.

MADDALA, G.S. Introdução à Econometria. $3^{\text {a }}$ edição. Rio de Janeiro: Livros Técnicos e Científicos; 2003.

MENDES, E.V. As redes de atenção à saúde. $2^{\text {a }}$ edição Brasília: Organização Pan-Americana da Saúde; 2011.

MORETTIN, P.A.; TOLOI, C. Análise de Séries Temporais. 2a edição. São Paulo: Egard Blucher; 2006.

NOVAES, M.L.O.; ALMEIDA, R.M.V.R.; BASTOS, R.R. "Previsão de Demanda da Vacina contra Difteria e Tétano pelo Método de Box-Jenkins ". In: XXII Congresso Brasileiro de Engenharia Biomédica, 4p., Rio de Janeiro, nov. 2010.

PELLEGRINI, F.R. Metodologia para implementação de sistemas de previsão de demanda [dissertação]. Porto Alegre: Universidade Federal do Rio Grande do Sul. Programa de Pós Graduação em Engenharia de Produção, 2000.

PINTO JÚNIOR, D.; SALGADO, P.O.; CHIANCA, T.C.M. Predictive validity of the Manchester Triage System: evaluation of outcomes of patients admitted to an emergency department. Rev Latino Am Enfermagem, v. 20, n. 6, p. 1041-7, 2012. DOI: http://dx.doi.org/10.1590/S0104-11692012000600005

R DEVELOPMENT CORE TEAM. R: A language and environment for statistical computing [Internet]. R Foundation for Statistical Computing: Vienna. Avaible on: http://www.R-project.org. Acessed on: 10 jan 2018.

ROSALES-LÓPEZ, A.; RAPOSO, L.M.; NOBRE, F.F.; ALMEIDA, R.T. The use of intervention analysis of the mortality rates from breast cancer in assessing the Brazilian screening programme. Res. Biomed. Eng. 2018 December; 34(4): 285-290. DOI: https://dx.doi.org/10.1590/2446-4740.180053.

ROTELA JUNIOR, P.; SALOMON, F.L.R.; PAMPLONA, E.O. Arima: an applied time series forecasting model for the bovespa stock index. Applied Mathematics. 2014; 5:3383-91. DOI:

https://dx.doi.org/10.4236/am.2014.521315.

SESMG, Secretaria de Estado de Saúde de Minas Gerais. Atenção à saúde do adulto: hipertensão e diabetes. Belo Horizonte, SAS/SAPS/SESMG; 2007. 
SHIRVANI, A.; MORADI, F.; MOOSAVI, A.A. Time series modelling of increased soil temperature anomalies during long period. International Agrophysics.2015; 29:509-15.

SIMÕES LHS, SILVA PCP. Identificação das receitas e custos na prestação de serviço em uma Unidade De Pronto Atendimento de Saúde - UPA. Encontro Brasileiro de Gestão Pública "A Construção da Administração Pública do Século XXI"; 2017.

TOMASI, E.; FACCHINI, L.A.; PICCINI, R.X.; OSORIO, A.; SILVEIRA, D.S.; SIQUEIRA, F.V.; et al. Características da utilização de serviços de Atenção Básica à Saúde nas regiões Sul e Nordeste do Brasil: diferenças por modelo de atenção. Ciência \& Saúde Coletiva. v. 16, n. 11, p. 4395-4404, 2011. DOI: http://dx.doi.org/10.1590/S1413-81232011001200012

WANG, C.C. A comparison study between fuzzy time series model and ARIMA model for forecasting Taiwan export. Expert Systems with Applications, v. 38, n. 8, p. 9296-304, 2011. DOI:

http://dx.doi.org/10.1016/j.eswa.2011.01.015

WERNER, L.; RIBEIRO, J.L.D. Previsão de demanda: uma aplicação dos modelos Box-Jenkins na área de assistência técnica de computadores pessoais. Rev Gestão \& Produção, v. 10, n. 1, p. 47-67, 2003. DOI: http://dx.doi.org/10.1590/S0104-530X2003000100005. 